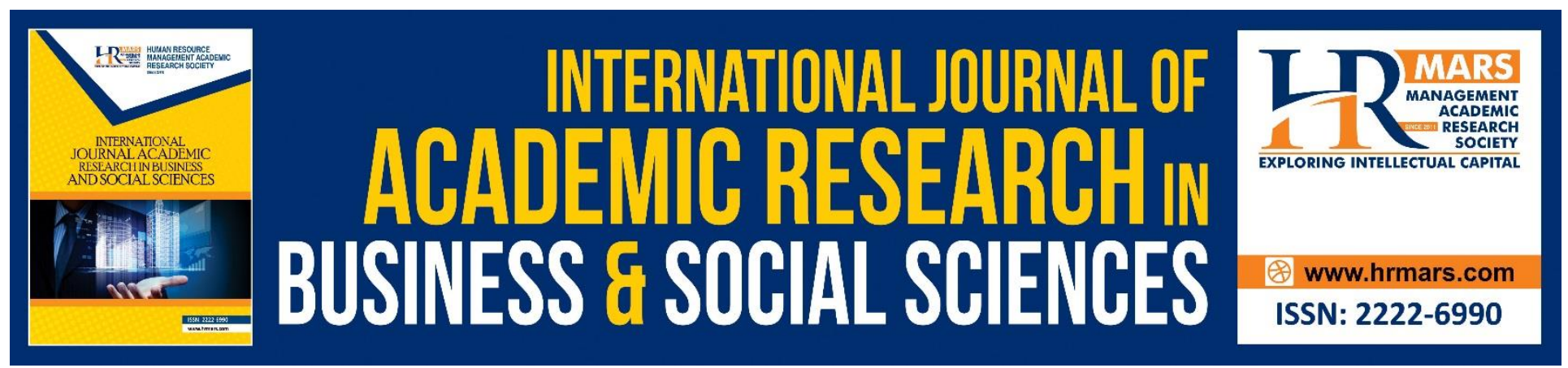

\title{
Availability of Infrastructure and Adoption of Point of Sales of Selected Small and Medium Enterprises (SMEs) in Lagos State, Nigeria
}

Akerejola, W. O., Okpara, E.U., Ohikhena, P., Emenike, P.O.

To Link this Article: http://dx.doi.org/10.6007/IJARBSS/v9-i1/5370 DOI: $10.6007 /$ IJARBSS/v9-i1/5370

Received: 17 Dec 2018, Revised: 06 Jan 2019, Accepted: 23 Jan 2019

Published Online: 25 Jan 2019

In-Text Citation: (Akerejola, Okpara, Ohikhena, \& Emenike, 2019)

To Cite this Article: Akerejola, W. O., Okpara, E. U., Ohikhena, P., \& Emenike, P. O. (2019). Availability of Infrastructure and Adoption of Point of Sales of Selected Small and Medium Enterprises (SMEs) in Lagos State, Nigeria. International Journal of Academic Research in Business and Social Sciences, 9(1), 137-150.

\section{Copyright: (c) 2019 The Author(s)}

Published by Human Resource Management Academic Research Society (www.hrmars.com)

This article is published under the Creative Commons Attribution (CC BY 4.0) license. Anyone may reproduce, distribute, translate and create derivative works of this article (for both commercial and non-commercial purposes), subject to full attribution to the original publication and authors. The full terms of this license may be seen at: http://creativecommons.org/licences/by/4.0/legalcode

Vol. 9, No. 1, 2019, Pg. 137 - 150

Full Terms \& Conditions of access and use can be found at http://hrmars.com/index.php/pages/detail/publication-ethics 


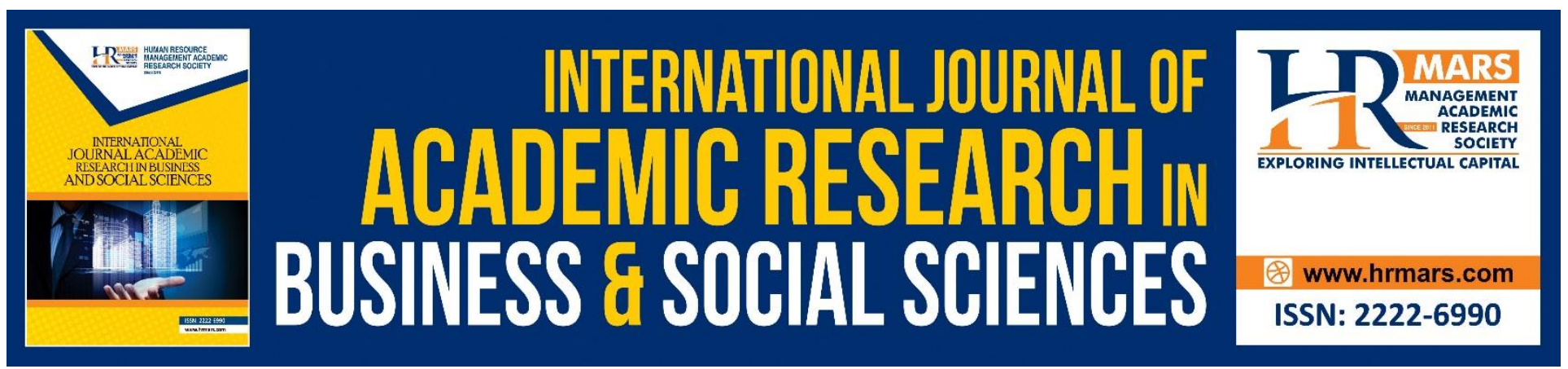

\title{
Availability of Infrastructure and Adoption of Point of Sales of Selected Small and Medium Enterprises (SMEs) in Lagos State, Nigeria
}

\author{
${ }^{1}$ Akerejola, W. O., ${ }^{2}$ Okpara, E.U., ${ }^{3}$ Ohikhena, P., ${ }^{4}$ Emenike, P.O. \\ ${ }^{1}$ Department of Business Administration, Wellspring University, Benin-City, Nigeria \\ ${ }^{2}$ Department of Accounting, Wellspring University, Benin-City, Nigeria \\ ${ }^{3}$ Department of Business Administration, Wellspring University, Benin-City, Nigeria \\ ${ }^{4}$ Emenike \& Co. Chartered Accountant - an Audit firm, Benin-City, Nigeria \\ Corresponding Author: ${ }^{1}$ Williams_sojumi@yahoo.com
}

\begin{abstract}
Nigerian payment systems are cash-driven and it is the main mode of payments transactions. However, the Point of Sales (POS), which is meant to encourage cashless economy as against the cashcentered operations, is challenged with issues of availability of infrastructure and security. This study examined the availability of infrastructure and adoption of POS of selected SMEs in Lagos state, Nigeria. The study adopted a cross-sectional survey research design. The population of the study consisted of selected SMEs who are users of POS in Lagos State estimated at 11,663 and sample size of 2,059 was adopted for the study. The respondents were selected from among the SMEs used for this study. A validated questionnaire from the sectors surveyed was used for the study. The sectors include: oil \& gas, banking and insurance, and manufacturing. A total of 2,059 copies of the questionnaire were administered, with a response rate of $77.1 \%$. The Cronbach's alpha coefficients for the constructs are 0.727 for adoption of POS, 0.799 for availability infrastructure and 0.758 for POS security. The data were analysed using descriptive and inferential (Pearson Product Moment correlation) statistics. The findings revealed that there was a significant relationship between availability of infrastructure and Adoption of POS $(r=0.407 ; p<0.01)$ and similar relationship also existed between POS security and Adoption of POS $(r=0.437 ; p<0.01)$. The study concluded that availability of infrastructure had significant and positive relationship with adoption of POS of selected business organisations who are SMEs in Lagos State, Nigeria. Thus recommended that there is need to ensure the adequate infrastructural availability by various stakeholders to adopt POS and assure of security of data transactions and reports generated using the device by the selected organizations in Lagos state, Nigeria.
\end{abstract}


INTERNATIONAL JOURNAL OF ACADEMIC RESEARCH IN BUSINESS AND SOCIAL SCIENCES

Vol. 9, No. 1, Jan, 2019, E-ISSN: $2222-6990$ (C) 2019 HRMARS

Keywords: availability of infrastructure, adoption of POS, e-payments, POS security

\section{Introduction}

Organizations have become increasingly dependent on technologically based information to support and drive operational, tactical and strategic business activities, thereby making information technology intrinsic in today's business enterprise (Okpara and Mohammed 2012).

Consequently, there is a global advancement in technological development; and Nigeria is not left out of this advancement. Information and Communications Technology (ICT) has evolved and has become a vehicle for technological growth in the economy of many societies as it has unarguably made life easier (Indjikian, Rouben Donald \& Siegel, 2005; Okpaku, 2003). Therefore, the global acceptance of Information and Communications Technology as well as its usage have attracted and received the interest of researchers who are on regular basis out to proffer solutions to problems related to technology development for decades (Davis, 1989; 1993; Park, Yang, \& Lehto, 2007). This development had prompted further research on the motivating factors for utilization and benefits of ICT and particularly its devices to several nations in order to improve their economic development (Indjikian, \& Siegel, 2005; Venkatesh, 2000).

In the work of Louho, Kallioja, and Oittinen (2006), technology acceptance is about how people accept and adopt some technological innovations to suite their peculiar needs. The user acceptance of technology has further been explained as the willingness within a user group to employ IT for the tasks it is designed to support (Dillion, \& Morris, 2001).

ICT infrastructure is a key element in the implementation or adoption of technology in an organisation. This infrastructure is composed by a set of hardware, software, services, and procedures, data security, power supply systems, processes and person, networking and peripherals and all the required devices to make it work, its continuous availability are key to the use of Point of Sales (POS) as they form the basis for their interconnectivity in an organisation, however this is inadequate, for example network failure, frequent power outage, unavailability of POS to merchants, and insufficient bandwidth are areas that needs improvement to encourage its adoption in an organisation as these have been inadequate and therefore slowed down its adoption (Adeoti, 2013; Adeoti \& Oshotimehin, 2012; Aguilar, Baquero \& Alejandro, 2004; Buabeng-Andoh, 2012; Ebietomere \& Ekuobase, 2014; Mohammed \& Mohammed, 2012).

This study is to make further contributions to the ongoing research and to focus specifically on how availability of infrastructure enhances the adoption of POS in selected organizations in Lagos state. In a recent study, it was observed that evolution of technology for use in financial transactions poses a lot of challenges as questions arose regarding the stability of the instrument in guaranteeing the efficiency and effectiveness of monetary policies of nations worldwide (Odior \& Banuso, 2012). From history, different payments systems have been used e.g. barter system was common, but double coincidence of want necessitated the use of coins and paper money. However, technological development gave rise to the use of superior instruments as with advancement in technology (Odior \& Banuso, 2012). However, developing economies like Nigeria are still at the introductory stage of the use of alternative payments platform as recently introduced by the monetary policy maker of Nigeria, the Central Bank of Nigeria (CBN) (Humphrey, 2004). Studies have shown that the use of cash for transactions made for payments of goods and services in many nations of the world is risky and 
complex, and is gradually giving way to alternative payments platform. This is because money outside the bank that is kept at a place other than the bank cannot be subjected to financial regulations and operational procedures by regulatory agency, and this limit the ability of the regulator to achieve the set objectives (Adeoti \& Oshotimehin, 2011).

In the CBN (2011) reports cited in Adeoti and Oshotimehin (2011), the cost of cash management was huge and given as follows: in 2009, CBN spent the sum of $\$ 114.6 \mathrm{~b}$, this rose to $\$ 135 b$ in 2010 , and $\$ 166$ b in 2011 , and an estimated sum of $\$ 196$ b was projected for 2012 , to manage currency production and services. These amounts are substantially large and require an urgent attention to address the situation, and this could be reduced to a minimal level should the economy embrace cashless and other alternative payments system especially POS. The result of this cashless system would be the reduction in the cost of printing currencies, cost of transportation of cash, cost of sorting currencies, and security cost of managing the printed currencies. Although an average Nigerian businessman prefers cash transactions and will embrace an alternative if they are well informed or educated of its benefits and assured of its transactional integrity. This therefore prompted the Federal government coming up with policy that upon implementation would reduce the volume of cash in the economy using Lagos as the pilot state. The acceptance and increase in the use of alternative payments platform (e-payments) notwithstanding, the adoption rate of POS was still low and this was attributable to inadequate awareness creation and security issues (Adeoti, 2013; Ebietomere \& Ekuobase, 2014; Mohammed \& Mohammed, 2012). A major challenge identified in the implementation of the cashless policy hinges on inadequate infrastructure such as epileptic power supply system, constant connectivity breakdown, insufficient hardware and software, inadequate bandwidth among others.

A CBN report shows the following data in volume of transactions as recorded in 2016: ATM 470,894,452; Cheques 9,764,546; Web 10,499,911; POS 47,743,919; (CBN, 2016) the data indicates low penetration of POS compare to ATM. Reasons given by CBN for low adoption rate of POS include but not limited to infrastructure issues and security of the transactions among others. This observation also indicated that many buyers of goods and services still do that by cash, this brings about enormous risk and high cost of cash management. It also brings about inefficiency and corruption (Omotayo \& Dahunsi, 2015). Similarly, as reported in Adeoti and Oshotimehin (2012), the general increase in the adoption rate of electronic payments instruments and the rate of growth in the adoption of POS are still low compared with other e-payments platform such as ATM.

Another issue of concern in the adoption of the POS technology in an organisation is security; this has been stressed in an article "challenges to the efficient use of POS terminals in Nigeria" (Adeoti, 2013). The author asserted that the efficient use of POS terminals in Nigeria will reduce the security challenges arising from fraud, and robbery occasioned by withdrawal of cash by unsuspecting customers from the bank. The importance of security of communication over the network as the network becomes available to the public is also of immense importance. Just like security on smart card a device used in POS terminal has become a critical issue as various transactions involving exchange of data and those through the internet must be well protected. The concern over the security of the smart card is premised on the need to prevent unauthorized access to critical data and other information of great importance by fraudsters and hackers who daily attempt breaking into systems. This is one of the problems the adoption of POS in an organization is meant to address 
(Taherdoost, Sahibuddin, \& Jalaliyoon, 2011). Similar research work done by Ebietomere and Ekuobase (2014) also aligns with the opinion that the adoption of the POS system will help check the rampant incidence of hacking into systems. Another study indicated that relying on traditional security control of physical access controls, security guards at the gate of the organisation securing their assets, processes and communications has become obsolete (Tarimo, 2006).

The complex nature of the device and the intelligence of hackers make it mandatory that adequate security be put in place in order to avoid or reduce the vulnerability of its use.

\section{Literature Review}

\section{Theoretical Foundation}

A number of theories have evolved to explain adoption of cashless based technological innovation including POS in an organization. One of the theories used in this study is Technology Acceptance Theory (Davis, 1989). This theory has two main constructs, which are perceived ease of use and perceived usefulness. Perceived ease of use posits that a person believes that using a particular system would be free of efforts and perceived usefulness believes using a system is useful for its operation. The two constructs aligned with the import of this study. Ease of use aligns with adequacy of infrastructure as constant breakdown or interruption of the device makes its use uneasy, and it is only when there is continuous flow of communications that its usefulness becomes obvious. Motivational theory of Davis and Warshaw (1992) as applied in Long (2010) to study information technology adoption and use was also applied in this study, especially the aspect of continuous network connectivity as a motivator to technology adoption. The Motivation Model suggests that individuals' behavior is based on two characteristics that is, extrinsic and intrinsic motivations. The study also uses The Unified Theory of Acceptance and use of Technology (Venkatesh, Morris, Davis \& Davis, 2003), which aims to explain user intention to use information system and subsequent usage behavior.

\section{Literature Review and Hypothesis Development}

In examining the implications of adoption of POS, it is necessary to look at how availability of infrastructure and POS security relates with the adoption of POS of selected SMEs in Lagos state, Nigeria.

The intention of earlier inventors of cash register was to create a system that will be used for recording cash transactions to prevent employee from unauthorized tampering with the revenue of the organisation (Ritty, 1879). This device soon became a tool for financial transactions as it issues receipts, functioning like sales as well as keeping the records and the reports generated from it. Improvements of technology over the years gave rise to what is today referred to as POS.

Cumbersomeness and risky nature of reliance on cash based economy in any society necessitate the adoption of POS, because money outside the banks cannot be subjected to regulatory and operational procedures and the ability of monetary policy to achieve set objectives in the presence of sizeable currency out of Bank is limited (Adeoti \& Oshotimehin, 2011) This simply means the adoption of POS signify the acquisition and usage of POS. 
POS as defined by some notable researchers is that it is a device used for recording transactions in a store, which can be said to be a modern day cash register (Shari, 2012). Gilaninia, Fattahi and Mousavian (2011) defined POS as a device that is installed in the center of the sale of goods and services instead of paying cash by physical transportation of money, the transaction amount from an account holder i.e. customer are deducted from their accounts electronically, using an electronic card, while the card acceptor (seller) is paid. Therefore, in this study, POS can be described as a device deployed in a merchant location where users swipe their electronic cards in order to make payment for purchases or services as against the use of cash.

Conceptually, there are benefits attributable to the use of POS. For example, World Bank says globally, the use of electronic payments systems was strategic in fast-tracking growth among the nations all over the world's financial sectors. For world body like the World Bank to emphasize the pivotal role of electronic payment system underscores its importance. Ashike, (2011) outlined the following benefits of electronic payment system:

1. Faster transactions, that is, reducing queue at the point of sale.

2. Improving hygiene on site, that is, eliminating bacteria through the spread of notes and coins;

3. Increase in sales, that is cash collection made simple.

4. Managing the entitlements of staff.

Other benefits include but not limited to the following: improves customer services, such as removes the need for invoice, cheques clearance etc; allow purchase and instant payments through the point of sale; discount to allow online purchases etc. The utilization of the electronic payments systems will also benefit stakeholders

Banks and card manufacturers have over the past decades been involved in processing of financial transaction electronically. The recent technological developments in the field of ecommerce have opened up other areas of development in the electronic payments system. First, the prospects of electronic commerce over the internet are creating a large demand for electronic payment methods for open networks. Secondly, the introduction of nation-wide electronic pursue schemes is creating many more opportunities where smart cards can be used for cost-effective offline payments. There is need for adequate security in POS electronically as the device is used to transact financial businesses.

In the Nation newspaper of Sunday July 16, 2017, on Cashless policy: Nigeria was reported to have incurred losses in billions, in addition to security concerns in banking application and POS (The Nation, 2017).

Visa International in its report showed that high net worth account holders neither own nor use ATM cards the channels of communications with POS, confirming that majority of the rich think that avoiding debit cards is the best way to stay protected from online fraud. IT infrastructure as a foundation to network connectivity and integrating all its multiservice devices enable two or more Computers connected together to facilitate information sharing between two or more users, that is facilitations of information sharing. That means provision of adequate IT infrastructures will facilitate the sharing of data, and other information that may be required by users in an organisation. Similarly, as a critical factor for success in POS adoption, the necessary infrastructure, such as internet access, that would make the cash-less policy to work in Nigeria should be made available or encouraged. 
Infrastructure is a key determinant of the adoption of POS in an organisation (Adebayo, Balogun, \& Kareem, 2013; Sajuyigbe, \& Alabi, 2012).

The main objective of this study is to examine availability of infrastructure and evaluate the relationship between POS security and adoption of Point of Sales of selected SMEs in Lagos State. In an attempt to come up with acceptable conclusions the study tested the following null hypothesis: $\mathrm{H}_{01}$ : There is no significant relationship between availability of infrastructure and adoption of POS of selected business organisations in Lagos State, Nigeria.

$\mathrm{H}_{02}$ : There is no significant relationship between POS security and adoption of POS of selected business organisations in Lagos State, Nigeria.

\section{Methodology}

This study employed a cross-sectional survey research design, employing well validated questionnaire as the main research instrument. This is consistent with the view of Mann (2003) who noted that many cross-sectional studies are completed with questionnaire and few others employ interviews to collect data. Similar studies on adoption of POS have employed a cross-sectional research design (Adeoti \& Oshotimehin, 2011). The justification for the use of this method is based on the need for Small and Medium scale business operators to understand the requirement of the study as the use of questionnaire simplified the extraction of opinion from the respondents. Furthermore, the focus on Small and Medium scale enterprises hinges on the fact that over $70 \%$ of businesses in Nigeria are of the SME type.

The population of the study consisted of all Small and Medium Enterprise (SMEs) who are the main users or adopters of POS in Lagos state and the collaborative survey conducted by Small and Medium Enterprises Development Agencies of Nigeria and National Bureau of Statistics in 2013, put the population at 11,663 in Lagos state. The total copies of questionnaire distributed was 2,059 and 1587 were returned representing about $77.1 \%$ of response rate.

Pilot study was conducted using small segments of the sample in order to confirm the validity and reliability of the instrument. The Cronbach's alpha coefficients for the constructs are 0.727 for adoption of POS and 0.799 for availability of infrastructure and 0.758 for POS security, showing the reliability of the instrument while the instrument was subjected to content validity - expert opinion validity as used by Osuagwu (2004).

The analysis of the study was conducted using descriptive and inferential statistics done through correlation and regression analysis. Specifically; Pearson Product Moment Correlation was used to measure the relationship between the study variables. 
INTERNATIONAL JOURNAL OF ACADEMIC RESEARCH IN BUSINESS AND SOCIAL SCIENCES

Vol. 9, No. 1, Jan, 2019, E-ISSN: 2222-6990 @ 2019 HRMARS

Data Analysis, Results and Discussion of Findings

The table below represents the respondents' responses from the administered questionnaire.

Table 1: Respondents' responses to availability of infrastructure

\begin{tabular}{|c|c|c|c|c|c|c|c|}
\hline$S / N$ & VARIABLES & SA & A & FA & FD & D & SD \\
\hline \multirow[t]{2}{*}{1} & \multirow{2}{*}{$\begin{array}{l}\text { Infrastructure is adequate if there is an easy } \\
\text { network and telecommunications availability. }\end{array}$} & 338 & 451 & 44 & - & 12 & 12 \\
\hline & & $\begin{array}{l}39.4 \\
\%\end{array}$ & $\begin{array}{l}52.6 \\
\%\end{array}$ & $\begin{array}{l}5.1 \\
\%\end{array}$ & - & $1.4 \%$ & $1.4 \%$ \\
\hline \multirow[t]{2}{*}{2} & \multirow{2}{*}{$\begin{array}{l}\text { Data security in the operation of POS is not } \\
\text { presently a problem. }\end{array}$} & 189 & 534 & 78 & 27 & 29 & - \\
\hline & & $\begin{array}{l}22.1 \\
\%\end{array}$ & $\begin{array}{l}62.3 \\
\%\end{array}$ & $\begin{array}{l}9.1 \\
\%\end{array}$ & $\begin{array}{l}3.2 \\
\%\end{array}$ & $3.4 \%$ & - \\
\hline \multirow[t]{2}{*}{3} & \multirow{2}{*}{$\begin{array}{l}\text { Hardware and Software integrity is highly in } \\
\text { place. }\end{array}$} & 210 & 486 & 149 & - & - & 12 \\
\hline & & $\begin{array}{l}24.5 \\
\%\end{array}$ & $\begin{array}{l}56.7 \\
\%\end{array}$ & $\begin{array}{l}17.4 \\
\%\end{array}$ & - & - & $1.4 \%$ \\
\hline \multirow[t]{2}{*}{4} & \multirow{2}{*}{$\begin{array}{l}\text { Power supply systems has aided the } \\
\text { implementation of POS. }\end{array}$} & 176 & 448 & 121 & 16 & 34 & 62 \\
\hline & & $\begin{array}{l}20.5 \\
\%\end{array}$ & $\begin{array}{l}52.3 \\
\%\end{array}$ & 14.1 & $\begin{array}{l}1.9 \\
\%\end{array}$ & $4.0 \%$ & $7.2 \%$ \\
\hline \multirow[t]{2}{*}{5} & \multirow{2}{*}{$\begin{array}{l}\text { Infrastructure is available if there is enough } \\
\text { bandwidth. }\end{array}$} & 242 & 459 & 122 & 22 & 12 & - \\
\hline & & $\begin{array}{l}28.2 \\
\%\end{array}$ & $\begin{array}{l}53.6 \\
\%\end{array}$ & $\begin{array}{l}14.2 \\
\%\end{array}$ & $\begin{array}{l}2.6 \\
\%\end{array}$ & $1.4 \%$ & - \\
\hline \multirow[t]{2}{*}{6} & \multirow{2}{*}{$\begin{array}{l}\text { Infrastructure is adequate if there is internet } \\
\text { Connectivity. }\end{array}$} & 266 & 456 & 117 & 18 & -- & - \\
\hline & & $\begin{array}{l}31.0 \\
\%\end{array}$ & $\begin{array}{l}53.2 \\
\%\end{array}$ & $\begin{array}{l}13.7 \\
\%\end{array}$ & $\begin{array}{l}2.1 \\
\%\end{array}$ & - & - \\
\hline
\end{tabular}

Source: Field Survey, 2016.

Table 1 shows responses by respondents in the questionnaire distributed and given as follows:

Statement 1 to 6 shows that majority of the respondents representing over $97 \%$ agreed that perceived ease of use, perceived usefulness, availability of adequate bandwidth, internet connectivity, adequate power supply systems, software integrity enhances the adoption of POS of selected SMEs in Lagos state, Nigeria. Similarly, they also agreed that when to be adopters perceived a device as having adequate security, they would be motivated to its adoption. 
INTERNATIONAL JOURNAL OF ACADEMIC RESEARCH IN BUSINESS AND SOCIAL SCIENCES

Vol. 9, No. 1, Jan, 2019, E-ISSN: 2222-6990 @ 2019 HRMARS

Table 2: Respondents' responses on Adoption of POS

\begin{tabular}{|c|c|c|c|c|c|c|c|}
\hline$S / N$ & Variables & SA & $A$ & FA & FD & $\mathrm{D}$ & SD \\
\hline \multirow[t]{2}{*}{1} & \multirow{2}{*}{$\begin{array}{l}\text { Experience is an important influence in adoption } \\
\text { of POS in an organisation. }\end{array}$} & 832 & 647 & 86 & 22 & - & - \\
\hline & & $57.8 \%$ & $37.5 \%$ & $4.0 \%$ & $0.8 \%$ & - & - \\
\hline \multirow[t]{2}{*}{2} & \multirow{2}{*}{$\begin{array}{l}\text { Innovativeness influences the adoption of POS in } \\
\text { an organisation. }\end{array}$} & 854 & 657 & 57 & 19 & - & - \\
\hline & & $58.9 \%$ & $37.8 \%$ & $2.6 \%$ & $0.7 \%$ & - & - \\
\hline \multirow[t]{2}{*}{3} & \multirow{2}{*}{$\begin{array}{l}\text { Availability of infrastructure enhances adoption of } \\
\text { POS in an organisation. }\end{array}$} & 1112 & 422 & 53 & - & - & - \\
\hline & & $74.2 \%$ & $23.5 \%$ & $2.4 \%$ & - & - & - \\
\hline \multirow[t]{2}{*}{4} & \multirow{2}{*}{$\begin{array}{l}\text { Perceived Ease of use of POS influences its } \\
\text { adoption }\end{array}$} & 835 & 740 & 12 & - & - & - \\
\hline & & $57.2 \%$ & $42.2 \%$ & $0.5 \%$ & - & - & - \\
\hline \multirow[t]{2}{*}{5} & \multirow{2}{*}{$\begin{array}{l}\text { Perceived usefulness of POS influences its } \\
\text { adoption }\end{array}$} & 679 & 803 & 105 & - & - & - \\
\hline & & $47.9 \%$ & $47.2 \%$ & $4.9 \%$ & - & - & - \\
\hline \multirow[t]{2}{*}{6} & \multirow{2}{*}{$\begin{array}{l}\text { Ease of communicating the benefits of POS } \\
\text { influences its adoption in an organisation }\end{array}$} & 628 & 870 & 70 & 19 & - & - \\
\hline & & $39.6 \%$ & $54.8 \%$ & $4.4 \%$ & $1.2 \%$ & - & - \\
\hline \multirow[t]{2}{*}{7} & \multirow{2}{*}{$\begin{array}{l}\text { Skill requirements of users of POS influences its } \\
\text { adoption }\end{array}$} & 679 & 809 & 99 & - & - & - \\
\hline & & $47.8 \%$ & $47.5 \%$ & $4.7 \%$ & - & - & - \\
\hline \multirow[t]{2}{*}{8} & \multirow{2}{*}{$\begin{array}{l}\text { Customer motivations will enhance the adoption } \\
\text { of POS in an organisation }\end{array}$} & 892 & 584 & 111 & - & - & - \\
\hline & & $61.4 \%$ & $33.5 \%$ & $5.1 \%$ & - & - & - \\
\hline \multirow[t]{2}{*}{9} & \multirow{2}{*}{$\begin{array}{l}\text { Government and regulations can enhance the } \\
\text { adoption of POS in an organisation }\end{array}$} & 728 & 698 & 161 & - & - & - \\
\hline & & $51.4 \%$ & $41.0 \%$ & $7.6 \%$ & - & - & - \\
\hline \multirow[t]{2}{*}{10} & \multirow{2}{*}{$\begin{array}{l}\text { Security of POS will enhanced the adoption of POS } \\
\text { in an organisation }\end{array}$} & 1051 & 439 & 97 & - & - & - \\
\hline & & $70.9 \%$ & $24.7 \%$ & $4.4 \%$ & - & - & - \\
\hline \multirow[t]{2}{*}{11} & \multirow{2}{*}{$\begin{array}{l}\text { Customer Trust on POS will enhance its adoption } \\
\text { in an organisation }\end{array}$} & 597 & 895 & 95 & - & - & - \\
\hline & & $44.5 \%$ & $55.5 \%$ & $4.7 \%$ & - & - & - \\
\hline \multirow[t]{2}{*}{12} & \multirow{2}{*}{$\begin{array}{l}\text { Information quality obtained from the use of POS } \\
\text { will enhance its adoption }\end{array}$} & 562 & 790 & 235 & - & - & - \\
\hline & & $40.8 \%$ & $47.8 \%$ & $11.4 \%$ & - & - & - \\
\hline
\end{tabular}

Source: Field survey, 2016

The response from participating respondents in Table 2 shows the following:

It is also noteworthy from the above table from Statement 1 to 12 that majority agreed with the assertion that experience, innovativeness, availability of infrastructure, ease of use of POS, perceived usefulness of POS, ability to communicate the benefits of POS to its users, skill requirements, motivation, government and regulations, security of POS, customer trust, and quality of information generated from POS enhances its adoption of selected business organisations in Lagos.

Comparing the interpretation of the responses in Table 1 and Table 2, it shows that customer trust enhances the adoption of POS in an organisation. 
INTERNATIONAL JOURNAL OF ACADEMIC RESEARCH IN BUSINESS AND SOCIAL SCIENCES

Vol. 9, No. 1, Jan, 2019, E-ISSN: 2222-6990 ㄷ 2019 HRMARS

Table 3: Pearson Product Correlation for availability of infrastructure and adoption of POS of selected business organizations in Lagos state

\begin{tabular}{|ll|l|l|}
\hline & & $\begin{array}{l}\text { Adoption of POS } \\
\text { in } \\
\text { Organisation }\end{array}$ & Availability of infrastructure \\
\hline Adoption of POS in & $\begin{array}{l}\text { Pearson } \\
\text { Sig. (2-tailed) }\end{array}$ & 1 & $.407^{* *}$ \\
Organisation test & $\mathrm{N}$ & 1587 & .000 \\
& $\begin{array}{l}\text { Pearson } \\
\text { of Correlation } \\
\text { Availability }\end{array}$ & $.407^{* *}$ & 1 \\
infrastructure & Sig. (2-tailed) & .000 & 1587 \\
& $\mathrm{~N}$ & 1587 & 1587 \\
\hline
\end{tabular}

Correlation is significant at the $\mathbf{0 . 0 1}$ level (2-tailed). Source: Field survey, 2016

Table .3 shows the significant relationship between customer trust and adoption of POS in an organisation. The correlation coefficient ( $r$ ) of customer trust to adoption of POS in an organization is .407 and the significance level is $0.01(p<.01)$. The null hypothesis was then rejected concluding that availability of infrastructure has a significant relationship on adoption of POS in Lagos.

Table 4: Respondents' responses on POS security

\begin{tabular}{|c|c|c|c|c|c|c|c|}
\hline$S / N$ & Variables & SA & A & FA & FD & D & SD \\
\hline \multirow[t]{2}{*}{1} & \multirow[t]{2}{*}{ Data security will enhance security capability of POS } & 350 & 988 & 144 & 51 & 54 & - \\
\hline & & $26.7 \%$ & $62.7 \%$ & $7.3 \%$ & $1.9 \%$ & $1.4 \%$ & - \\
\hline \multirow[t]{2}{*}{2} & \multirow[t]{2}{*}{ Software security will aid POS security } & 389 & 900 & 276 & - & - & 22 \\
\hline & & $29.3 \%$ & $56.5 \%$ & $13.9 \%$ & - & - & $0.3 \%$ \\
\hline \multirow[t]{2}{*}{3} & \multirow{2}{*}{$\begin{array}{l}\text { Ability to secure critical data in POS enhances its } \\
\text { security capability. }\end{array}$} & 525 & 918 & 119 & 3 & 22 & - \\
\hline & & $38.1 \%$ & $55.5 \%$ & $5.8 \%$ & $0.1 \%$ & $0.5 \%$ & - \\
\hline \multirow[t]{2}{*}{4} & \multirow{2}{*}{$\begin{array}{l}\text { Security across communication network will } \\
\text { necessarily leads to adoption of POS. }\end{array}$} & 656 & 714 & 173 & 22 & - & 22 \\
\hline & & $47.5 \%$ & $43.1 \%$ & $8.4 \%$ & $0.8 \%$ & - & $0.3 \%$ \\
\hline \multirow[t]{2}{*}{5} & \multirow[t]{2}{*}{ Physical security of POS will encourage its adoption. } & 616 & 876 & 73 & - & - & 22 \\
\hline & & $44.1 \%$ & $52.2 \%$ & $3.5 \%$ & - & - & $0.3 \%$ \\
\hline \multirow[t]{2}{*}{6} & \multirow[t]{2}{*}{ Different layers of security will encourage POS usage. } & 823 & 606 & 117 & 19 & - & 22 \\
\hline & & $58.1 \%$ & $35.7 \%$ & $5.5 \%$ & $0.7 \%$ & - & $0.3 \%$ \\
\hline \multirow[t]{2}{*}{7} & \multirow[t]{2}{*}{ There is high level of confidentiality in POS } & 576 & 836 & 99 & 19 & 19 & 38 \\
\hline & & $36.3 \%$ & $52.7 \%$ & $6.2 \%$ & $1.2 \%$ & $1.2 \%$ & $2.4 \%$ \\
\hline \multirow[t]{2}{*}{8} & \multirow{2}{*}{$\begin{array}{l}\text { Non disclosure of personal information in POS will } \\
\text { enhance its security. }\end{array}$} & 675 & 741 & 168 & 3 & - & - \\
\hline & & $42.5 \%$ & $46.7 \%$ & $10.6 \%$ & $0.2 \%$ & - & - \\
\hline \multirow[t]{2}{*}{9} & \multirow{2}{*}{$\begin{array}{l}\text { Availability of superior anti-hackers software to } \\
\text { protect the network will enhance POS security } \\
\text { capability. }\end{array}$} & 549 & 592 & 246 & 181 & - & 19 \\
\hline & & $42.2 \%$ & $37.9 \%$ & $12.6 \%$ & $7.0 \%$ & & $0.2 \%$ \\
\hline
\end{tabular}

\section{Source: Field survey, 2016}

Table 4 shows responses by respondents as follows: 
INTERNATIONAL JOURNAL OF ACADEMIC RESEARCH IN BUSINESS AND SOCIAL SCIENCES Vol. 9, No. 1, Jan, 2019, E-ISSN: 2222-6990 (C) 2019 HRMARS

Statement 1 through to 9 also shows that majority of the respondents agreed that data security on POS, software security, securing critical data in POS, security across communication network, physical security of POS, securing layers across network, high level of confidentiality in POS, non-disclosure of personal information in POS, availability of superior anti-hackers software to protect the network will enhance POS security of selected business organisations in Lagos.

Comparing the interpretation of the responses in Table 4 and Table 2 clearly shows that POS security has a positive relationship with adoption of POS of selected business organizations in Lagos.

Table 5: $\quad$ Pearson Product Correlation for POS security

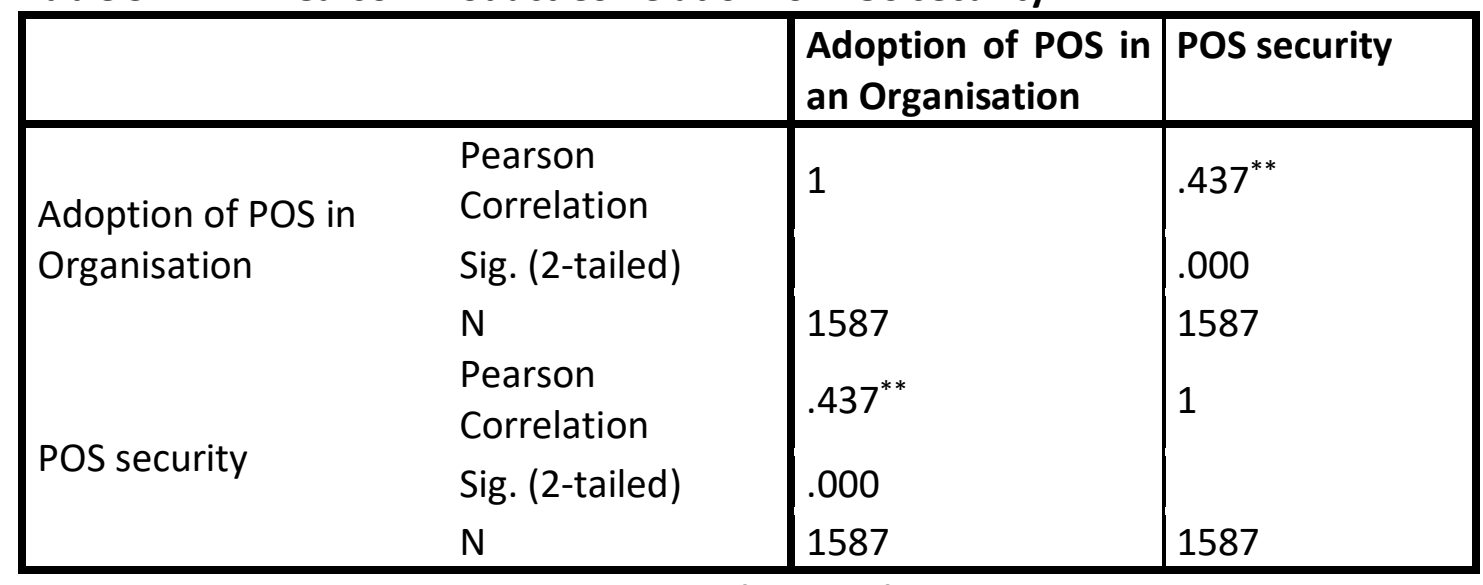

Correlation is significant at the 0.01 level (2-tailed). Source: Field survey, 2016

Table 5 shows the significant relationship between POS security and adoption of POS in an organisation. The correlation coefficient ( $r$ ) of security of POS to adoption of POS in an organisation is .437 and the significance level is $0.01(p<.01)$. The null hypothesis was therefore rejected concluding that POS security has a positive and significant relationship on adoption of POS of selected business organisations in Lagos.

\section{Conclusions and Recommendation}

Based on the analysis of this study, hypotheses testing and interpretation of results it was observed that availability of infrastructure and POS security has positive relationship with the adoption of POS of selected SMEs in Lagos state.

\section{Conclusion}

In conclusion the result of the analysis of this study shows the importance of the adoption of POS of selected SMEs in Lagos state. Aside stressing the importance of availability of infrastructure which was identified as the foundation and an important element of the requirements for adoption of POS of selected SMEs in Lagos state, adequate security must be provided. The choice of POS which is a device for electronic payments systems was also to reduce the risk involved in carrying cash and the attendant consequences. So also is the reduction of cost of cash printings. 


\section{Recommendations}

The result of the analysis of this study shows the importance of the adoption of POS of selected business organisations in Lagos state. Infrastructure provision must be taking as an important component in adoption of POS, not only provided but also adequate.

Operators are encouraged to keep improving on the security of POS as this is found to have a positive and significant relationship with adoption of POS. This will engender customers' confidence in the use of POS.

It is recommended to operators and other stakeholders in this sector to ensure that in order to encourage the user adoption of POS, continuous provision of power supply, high bandwidth, and good network connectivity are made to motivate the adoption of POS. It is recommended that government should provide enabling environment that will provide the needed infrastructure for adoption of POS. Financial institutions should also assist in providing the needed funds for infrastructure development for POS

\section{REFERENCES}

Adeoti, O. O. (2013). Challenges to the efficient use of Point of Sales terminals in Nigeria, Africa Journal of Business Management, 7(28), 2801-2806.

Adeoti, O. O., \& Oshotimehin, K. O. (2011). Factors influencing adoption of point of sale terminals in Nigeria. Journal of Emerging Trends in Economicsb and Management Sciences (JETEMS), 2(5), 388-392.

Adeoti, O., \& Oshotimehin, K. (2012). Adoption of Point of Sale terminals in Nigeria, Assessment of consumer's level of satisfaction, Research Journal of Finance and Accounting. 3(1).

Adesina, A. A., \& Ayo, C. K. (2010). An Empirical investigation of the level of users' Acceptance of eBanking and Ccmmerce, Journal of Internet Banking and Commerce, 15(1).

Ayo, C. K., Adewoye, J. O., \& Oni, A. A. (2010). The State of e-Banking Implementation in Lagos: A Post-Consolidation Review, Journal of Emerging Trends in Economics and Management Sciences.

Bestavros, A. (2000). Banking industry walks 'tightrope' in personalization of web services. Bank Systems \& Technology 37(1), 54-56.

CBN, (2011). Central Bank of Nigeria Annual Economic Report, 2011.

CBN, (2012). Central Bank of Nigeria Annual Economic Report, 2012.

CBN, (2015). Central Bank of Nigeria Annual Economic Report, 2015.

CBN, (2016). Central Bank of Nigeria Financial Systems Stability Report, 2016.

Cobb, A. (2005). http://www.ameinfo.com/50050.html.

Davis, F. D. (1989). Perceived usefulness, perceived ease of use, and user acceptance of information technology, MIS Quarterly 13(3), 319- 340.

Davis, F. D., Bagozzi, P. R., \& Warshaw,. (1993). User acceptance of Computer technology: A comparison of two theoretical models. Management Science, 35(8), 982-1003.

Day, G. S. (1991). Learning about markets. Marketing Science Institute Report, 91-117 (June). Cambridge, MA: Marketing Science Institute.

Dillon, A. and Morris, C. (2001). User Acceptance of Information Technology. Encyclopedia of Human Factors and Ergonomics. London: Taylor and Francis. 
INTERNATIONAL JOURNAL OF ACADEMIC RESEARCH IN BUSINESS AND SOCIAL SCIENCES

Vol. 9, No. 1, Jan, 2019, E-ISSN: 2222-6990 @ 2019 HRMARS

Ebietomere, E. P., \& Ekuobase, G. O. (2014). Issues on mobile agent technology adoption, African Journal of Computing \& ICT. 7(1), $21-32$.

Fulmer, J. (2009). What in the world is infrastructure?. PEI Infrastructure Investor (July/August): 3032.

Gilaninia, S., Fattahi, A. \& Mousavian, S. J. (2011). Behavioral factors tend to use the Internet banking services case study: System (SABA), the Melli Bank, Iran, Ardabil, International Journal of Business Administration, 2(3), 173-179.

Guardian, (2015). Cyber Act: Making it work for e-payments.

Hancock, D., \& Humphry, D. (1998). Payment transactions, instrument and systems: A survey. Journal of Banking and Finance. 1573 - 1624.

Humphrey, D. B. (2004). Replacement of cash by cards in U.S. Consumer Payments, Journal of Economics and Business, 56, 211-225.

Indjikian, Rouben, Siegel, \& Donald, S. (2005). The impact of investment in IT on economic performance: Implications for developing countries. World development, 33(5), 681-700.

Kalakota, R. \& Whinston, A. (1997). Electronic commerce: a manager's guide. Addison- Wesley.

Kapurubandara, M., \& Lawson, R. (2006). Barriers adopting ICT and e-commerce with MEs in developing Countries: An Exploratory Study in Sri Lanka.

Ladokun, I. O., Osunwole, O. O., \& Olaoye, B. O. (2013). Information and communications technology in small and medium enterprises, Factors affecting the adoption and use of ICT in Nigeria. International Journal of Academic Research in Economics and Management Sciences, 2(6), 74 -84 .

Lewis, J., \& Weigert, A. (1984). Trust as a social reality. Social Forces, 963 - 967.

Mcknight, D. H., \& Chervany, N. L. (1996). The meanings of trust. University of Minnesota MIS Research Center Working Paper series, WP 96-04, Available at <http://misrc.umn.edu/wpaper/WorkingPapers/9604.pdf> Access February 09, 2013

Mohammed, A. I., \& Mohammed, A.Y. (2012). Factors influencing the adoption of e-banking in Sudan: perceptions of retail banking clients: Journal of internet banking and commerce,17(3). <http://www.arraydev.com/commerce/jibc/>.

Nigeria Inter-bank Settlement System (NIBSS). (2012). Lagos PoS adoption survey. Project Report conducted by Financial Derivatives Company Ltd, 1-131.

Nigeria Inter-bank Settlement System (NIBSS) (2015). PoS adoption and usage - A study on Nigeria State, 1-105.

Okpaku, \& Joseph, O. (2003). Information and Communications Technologies for African Development. An Assessment of Progress and the Challenges Ahead. New York: United Nations ICT Task Force.

Okpara E. \& Mohammed U. (2012). Behavioural Factors as Correlate of the Use of Information Communication Technology (ICT) in the Nigerian Army: The Case Study of Nigerian Army Signals Corps. Journal of Emerging Trends in Economics and Management Sciences (JETEMS). Volume 3 (6).

Omotayo, F., \& Dahunsi, O. (2015). Factors affecting adoption of point of sales terminals by Business organisation in Nigeria. International Journal of Academic Research in Business and Social Sciences. 5(10), $115-136$. 
INTERNATIONAL JOURNAL OF ACADEMIC RESEARCH IN BUSINESS AND SOCIAL SCIENCES

Vol. 9, No. 1, Jan, 2019, E-ISSN: 2222-6990 (C) 2019 HRMARS

Osuagwu,( 2004). Relationship marketing strategies in Nigerian companies, The Marketing Management Journal, 14(2), 114-128.

Oyetade, L., \& Ofoelue O., (2012). Nachmais, \& Nachmais, (1982), Research Methods in Social Sciences, Edward Arnold Publishers Itd., London.

Paltridge, S. (2008). Global opportunities for internet access developments. On-line. Paris: $\mathrm{OECD} /$ Directorate for science, technology and industry /development corporation directorate.

Park, J., Yang, S., \& Lehto, X. (2007). Adoption of mobile technologies for Chinese Consumers. Journal of electronic commerce research, 8(3), 196-206.

Ramayah, T., Yan, L. C. \& Sulaiman, M. (2005). SME e-readiness is it unidimensional or multidimensional? Journal of Management.

Ritty, J. (1879). Today in History: Ritty's incorruptible cashier.

Taherdoost, H., Sahibuddin, S., \& Jalaliyoon, N. (2011). Smart card security; Technology and Adoption. The Nation, (2017). Cashless policy: Nigerian count losses in billions

Venkatesh, V., \& Davis, F. D. (2000). A Theoretical Extension of the Technology Acceptance Model: Four Longitudinal Field Studies, Management Science 46(2), 186-204.

Venkatesh, V., Thong, J. Y. L., \& Xin, X. (2012). Consumer acceptance and use of information technology: Extending the unified theory of acceptance and use of technology. MIS Quarterly, 36 (1), 157-178.

World Bank Group (2006). 2006 Information and communications for development. Global trends and policies. Washington DC: World Bank

Yamane, Y. (1967). Statistics: An Introductory Analysis, ( $2^{\text {nd }}$ Edn), New York: Harper and Row.

Zhen-Wei, Q., Christine; Pitt, Alexander; Ayers, \& Seth, (2004). Contribution of Information and Communication Technologies to Growth. World Bank working paper. Washington DC: World Bank. 